\title{
First Report of Serratia plymuthica Causing Onion Bulb Rot in Poland
}

\author{
BEATA KOWALSKA*, URSZULA SMOLIŃSKA and MICHAŁ OSKIERA
}

Institute of Horticulture, Skierniewice, Poland

Received 6 January 2010, revised 18 December 2010, accepted 20 December 2010

\author{
Abstract
}

Specific bacterial disease symptoms were observed on onion bulbs in almost all regions in Poland. For the purpose of identification of agents causing disease, bacteria were isolated from the symptomatic plants. Their pathogenicity was confirmed by using pathogenicity test on onion scales. These bacteria were identified biochemically and molecularly as Serratia plymuthica.

Key words: Serratia plymuthica, bacterial disease, onion

Onion (Allium cepa L.) is one of the major vegetable crops grown in Poland. Since the onion harvesting period often coincides with rainy weather and during cultivation it may hail, complex bacterial and fungal diseases often occur. In the last years especially bacterial diseases of onion cause very serious problems in Poland. These diseases may cause significant economic losses because they are difficult to control. Bacterial soft of onion bulbs is the most frequent and it can appear during cultivation, storage or transportation. It is common knowledge that in Poland, bacterial diseases of onion are caused by Burkholderia gladioli, Burkholderia cepacia, Pectobacterium carotovorum subsp. carotovorum (Sobiczewski and Schollenberger, 2002). Foreign reports conclude that bacteriosis of onion can also be caused by Pseudomonas marginalis (Kim et al., 2002; El-Hendawy, 2004), Pseudomonas syringae, Pseudomonas viridiflava (Gitaitis et al., 1998), Pantoea ananatis (Gitaitis et al., 2002), Enterobacter cloacae (Schroeder et al., 2009; Schwartz and Mohan, 2008), Burkholderia ambifaria and Burkholderia pyrrocinia (Jacobs et al., 2008). Also bacterium Serratia spp. was noted as an onion pathogen in Brasil (Beriam, 2007). The liberalization of policies concerning border protection and intense trade favor transmission of pathogens from foreign countries.

During the summer and autumn of 2003, 2006 and 2007, disease symptoms of unknown origin were observed on onion (Allium cepa L.) bulbs in the field and storage houses in different places in Poland. These symptoms were typical for bacterial disease - water soaked and pale brown lesions appeared on the internal scales, they enlarged and extended to external scales with an associated sour smell. Bacteria from the infected bulb tissues were isolated and purified on nutrient agar. About forty isolates were obtained and these isolates were examined for the ability to macerate onion tissue. The pathogenicity test was conducted on healthy onion bulbs $c v$. Grabowska. The bulbs were peeled, washed with running water and sterilized in 70\% ethanol for $30 \mathrm{sec}$ and in $0.5 \% \mathrm{NaOCl}$ for $5 \mathrm{~min}$. The bulbs were washed in sterile water and cut lengthwise into two parts. Three onion pieces were placed, cut side down, into a Petri dish (180 $\mathrm{mm}$ in diameter). The outer scale of each piece was wounded with the microbiological needle and inoculated by $20-\mu$ l aliquot of bacterial suspension of density $1.0-2.5 \times 10^{8} \mathrm{cfu} / \mathrm{ml}$. For each isolate three Petri dishes were included. Control treatment remained uninoculated. The Petri dishes were incubated 4 days at $28^{\circ} \mathrm{C}$. Nine of forty isolates expressed rot symptoms on the scales. These isolates were studied by using biochemical and molecular methods.

Biochemical identification of the isolates were performed by using the API 20E system (bioMerieux) which gave a bacterial code of 1207763 (Table I)

\footnotetext{
* Corresponding author: B. Kowalska, Institute of Horticulture, Konstytucji 3 Maja 1/3; 96-100 Skierniewice, Poland; e-mail: beatakow@iwarz.pl
} 
Table I

Biochemical profile of tested isolates conducted using identification system API 20E

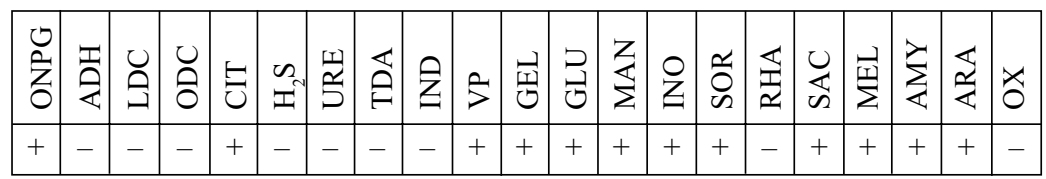

\begin{tabular}{|l|l|}
\hline test & reactions / enzymes \\
\hline ONPG & $\beta$-galactosidase \\
\hline ADH & arginine dihydrolase \\
\hline LDC & lysine decarboxylase \\
\hline ODC & ornithine decarboxylase \\
\hline CIT & citrate utilization \\
\hline $\mathrm{H}_{2} \mathrm{~S}$ & $\mathrm{H}_{2}$ S production \\
\hline URE & urease \\
\hline TDA & tryptophane deaminase \\
\hline IND & indole production \\
\hline VP & acetoin production \\
\hline GEL & gelatinase \\
\hline GLU & fermentation / oxidation (glucose) \\
\hline MAN & fermentation / oxidation (mannitol) \\
\hline INO & fermentation / oxidation (inositol) \\
\hline SOR & fermentation / oxidation (sorbitol) \\
\hline RHA & fermentation / oxidation (rhamnose) \\
\hline SAC & fermentation / oxidation (saccharose) \\
\hline MEL & fermentation / oxidation (melibiose) \\
\hline AMY & fermentation / oxidation (amygdalin) \\
\hline ARA & fermentation / oxidation (arabinose) \\
\hline OX & cytochrome oxidase \\
\hline & \\
\hline
\end{tabular}

$(\%$ identity $=59.6 ; \mathrm{T}=1.0)$. The numerical profile showed a correct identification of all examined strains as Serratia plymuthica. Additionally, some biochemi- cal tests were conducted. The microorganisms were Gram-negative, catalase positive, oxidase negative and grew in anaerobic condition.

\title{
AJ233433.1 CGTGTGTGAAGAAGGCCTTAGGGTTGTAAAGCACTTTCAGCGAGGAGGAAGGG--CAGTG \\ |||||||||||||||||||||||||||||||||||||||||||||||||| ||||| \\ HM596429.1361 CGTGTGTGAAGAAGGCCTTAGGGTTGTAAAGCACTTTCAGCGAGGAGGAAGGGTTCAGTG \\ ||||||||||||||||||||||||||||||||||||||||||||||||||||||||| |||
}

AY394724.1 CGTGTGTGAAGAAGGCCTTAGGGTTGTAAAGCACTTTCAGCGAGGAGGAAGGGTAGTGTG

\author{
AJ233433.1 TTAATAGCACAT-TGCATTGACGTTACTCGCAGAAGAAGCACCGGCTAACTCCGTGCCAG \\ |||||||||| | | | |||||||||||||||||||||||||||||||||||||||||||
}

HM596429.1 421 TTAATAGCAC-TGTRCATTGACGTTACTCGCAGAAGAAGCACCGGCTAACTCCGTGCCAG

AY394724.1 TTAATAGCACAT-TRCATTGACGTTACTCGCAGAAGAAGCACCGGCTAACTCCGTGCCAG

\section{AJ233433.1 AGAA-TT-CGCTAGAGATAGCTTAGTGCCTTCGGGAACTCTGAGACAGGTGCTGCATGGC \\ |||| || | | |||||| | || |||||||||||||||||||||||||||||||||||}

HM596429.1960 AGAACTTTC-C-AGAGATGGATTGGTGCCTTCGGGAACTCTGAGACAGGTGCTGCATGGC

|||||||||||||||||||||||||||||||||||||||||||||||||||||||||||||||

AY394724.1 AGAACTTTC-C-AGAGATGGATTGGTGCCTTCGGGAACTCTGAGACAGGTGCTGCATGGC

Fig. 1. Homology sequence alignment of the 16S rRNA region of type strain S. plymuthica DSM 4540 acc. no. AJ233433.1, tested isolate 466 acc. no HM596429.1, strain of the nearest BLAST match S. plymuthica RVH1 acc. no AY394724.1. Sequences were retrieved from the GenBank (National Center for Biotechnology Information) database under the accession numbers indicated. 
Table II

BLAST search results for 16S rRNA gene sequence of representative isolate 466

\begin{tabular}{|l|l|l|c|c|}
\hline \multicolumn{1}{|c|}{ S. plymuthica isolate } & Accession no & \multicolumn{1}{c|}{ Country } & Identity & Match \\
\hline DSM 4540 - type strain & AJ233433.1 & Germany & $98.9 \%$ & $1449 / 1465$ \\
\hline $466-$ tested isolate & HM596429.1 & Poland & $100 \%$ & $1460 / 1460$ \\
\hline RVH1 & AY394724.1 & Belgium & $99.7 \%$ & $1456 / 1461$ \\
\hline
\end{tabular}

The identity of the isolates was confirmed by molecular techniques - 16S rRNA sequence analysis. DNA was isolated by "Genomic mini" kit according to producent's clues (A \& A Biotechnology). The 16S rDNAs were amplified by using universal primers fD1 (5'AGAGTTTGATCMTGGCTC3') and rP2 (5'ACGGCTACCTTGTTACGACTT3') (Weisburg et al., 1991). Additional sequensing primers were used: 800f (5'ATTAGATACCCTGGTAG3') and 800r (5'CTACCAGGGTATCTAAT3') (Fouad et al., 2002). The amplified PCR products, lenght $1500 \mathrm{bp}$, were separated by $1.5 \%$ agarose gel electrophoresis, then extracted and purified from gel with the DNA Fragment Purification Kit (A \& A Biotechnology). DNA sequences were compared to NCBI database (www. ncbi.nlm.nih.gov) using BLAST program (Basic Local Alignment Search Tool), demonstrated that 16S rRNA gene of the studied isolates of bacteria shared high identities (99.7\%) with Serratia plymuthica RVH1, NCBI GenBank database accession no. AY394724.1 (Fig. 1, Table II). The 16S rRNA sequence of the one representative isolate (466) has been deposited in the GenBank database under the accession number HM596429.1.

The biochemical test data along with sequence analysis of a portion of the 16S rRNA gene confirmed all the isolates to be Serratia plymuthica. According to our knowledge, this is the first report of S. plymuthica causing a bulb rot of onion in Poland.

\section{Acknowledgments}

This work was supported by grant NN 310299734

\section{Literature}

Beriam L.O. S. 2007. Palestra doencas bacterianas em hortalicas. Biologico 69: 81-84.

El-Hendawy H.H. 2004. Association of pectolytic fluorescent pseudomonads with postharvest rots of onion. Phytopathol. Mediterr. 43: 369-376.

Fouad A.F., J. Barry, M. Caimano, M. Clawson, Q. Zhu, Carver R., K. Hazlett and J.D. Radolf. 2002. PCR-based identification of bacteria associated with endodontic infections. J. Clin. Microbiol. 40: 3223-3231.

Gitaitis R., G. MacDonald, R. Torrance, R. Hartley, D.R. Sumner, J.D. Gay and W.C. Jahnson. 1998. Bacterial streak and bulb rot of sweet onion: II. Epiphytic survival of Pseudomonas viridiflava in association with multiple weed hosts. Plant Dis. 82: 935-938.

Gitaitis R., R. Walcott, S. Culpepper, H. Sanders, L. Zolobowska and D. Langston. 2002. Recovery of Pantoea ananatis, casual agent of center rot of onion, from weeds and crops in Georgia, USA. Crop Protect. 21: 983-989.

Jacobs J.L., A.C. Fasi, A. Ramette., J.J. Smith, R. Hammerschmidt and G.W. Sundin. 2008. Identification and onion pathogenicity of Burkholderia cepacia complex isolates from the onion rhizosphere and onion field soil. Appl. Environ. Microbiol. 74: 3121-3129.

Kim Y.K., S.D. Lee, C.S. Choi, S.B. Lee and S.Y. Lee. 2002. Soft rot of onion bulbs caused by Pseudomonas marginalis under low temperature storage. Plant Pathol. J. 18: 199-203.

Schroeder B.K., L.J. du Toit and H.F. Schwartz. 2009. First report of Enterobacter cloacae causing onion bulb rot in the Columbia Basin of Washington State. Plant Dis. 93: 323.

Sobiczewski P. and M. Schollenberger. 2002. Bacterial deseases of horticulture plants (in Polish). pp. 64-67; 54-57. Państwowe Wydawnictwo Rolnicze i Leśne. Warszawa.

Schwartz H.F. and S.K. Mohan. 2008. Compendium of onion and garlic diseases and pests. APS PRESS, St. Paul, Minnesota, USA. Weisburg W.G., S.M. Barns, D.A. Pelletier and D.J. Lane. 1991. 16S ribosomal DNA amplification for phylogenetic study. J. Bacteriol. 173: 697-703. 